\title{
The Effect of Composting on the Organic Colloidal Fraction from Domestic Sewage Sludge
}

\author{
Gonzalo Almendros ${ }^{1}$, Juan A. Leal ${ }^{2}$, Francisco Martin ${ }^{3}$ \\ and Francisco J. Gonzalez-Vila
}

I Instituto de Edafologia y Biologia Vegetal (C.S.I.C.), Serrano 115 dpdo, 28006-Madrid, Spain

${ }^{2}$ Centro de Investigaciones Biologicas (C.S.I.C.), Velazquez 144, 28006-Madrid, Spain

3 Instituto de Recursos Naturales y Agrobiologia (C.S.I.C.), Apartado 1052 , 41080-Sevilla, Spain

\section{Abstract}

Due to the frequent use of domestic sewage sludges as organic additives to soils with low humus content, the chemical characteristics of the extractable polymers from composted and uncomposted sludges were described.

The alkali-soluble, acid-insoluble sludge fraction (humic-like) was isolated after exhaustive lipid extraction, and analyzed by chemical degradation followed by combined gas chromatography mass spectrometry. It was observed that this sludge fraction contained an important amount of lipid compounds (more than $40 \%$ by weight). Most of this lipid material can be physically removed, but the residual polymer fractions were also found to be highly aliphatic in nature. The high yields upon degradation of several types of alkanoic acids and the relatively high proportion of polypeptides ( $30 \%$ by weight), as well as carbohydrates, suggested that the humic-like fractions from both the composted and uncomposted sludges consisted of slightly altered microbial and residual biopolymers. The effects of composting sludge mainly concern the selective biodegradation of the less resistant moieties. The great differences between the chemical nature of the humic-like fraction of the composted sludge and that of the soil humic acids are considered to reflect the low proportion of lignified materials in the original sludge.

\section{Introduction}

The use of domestic sewage sludge for agricultural purposes requires that the organic composition of the sludge be characterized first, including the analysis of potentially harmful pollutants $[1,2]$. Sewage sludge seems to be an important source of readily biodegradable organic matter [3], and its favourable effects on the physical properties of soils $[4]$ and its high nitrogen content $[5,6]$ are generally considered to be sufficient to justify the use of sewage sludge on agricultural soil. On the other hand, the often high 
proportion of heavy metals and phytotoxic substances, as well as the problems derived from certain microbial species, set an upper limit for the direct use of sludge on land; the first aspect is particularly pronounced in acid soils.

The study of the chemical nature of the extractable polymers from sludges is also important in establishing their potential fertility and their degree of "maturity". In general, the humic acid content is often used to evaluate organic fertilizers, although humic substances do not seem to be present, at least in sensu strictu, in the products derived from urban wastes [7]. The humic acid fractions are usually defined in terms of the procedures used for their extraction (solubility in alkali and insolubility in acid), although the use of such criteria is inadequate for organic material other than soil $[8,9]$. For this reason, the organic matter extracted from sludge by the same methods as used for the isolation of humic acids will be referred to in the present paper as the "organic colloidal fraction" (OCF). This sludge fraction is presumably most active in terms of its physico-chemical properties. In addition, during laboratory isolations of soil humus constituents, the sludge OCF's are coextracted together with the humic acids in soils amended with sludge. Consequently, the chemical characterization of such sludge polymer fractions is also useful for predicting the short-term changes in the humic fraction from sludge-amended soils [10]. Differences between the organic matter composition of sludge and humus may be partially due to the reduced period of aerobic evolution of the former; the "sludge humic acids" are frequently compared with the aquatic humic substances [11]. These facts suggest the importance of the oxidative processes in transforming sewage sludge into a material looking more like soil humus. Taking into account the above criteria, the aim of the present study was to examine the presence of humic-type polymer fractions in the composted sludge.

\section{Material and Methods}

\section{Sewage Sludge}

The sample studied was representative domestic sewage sludge from the treatment station of Camino de la Muñoza, Almeria (Spain). The final product after aerobic and anaerobic treatments was air-dried and ground before analyses.

In the composting experiment the material was incubated for 4 months in a $40-1$ polyethylene container in a chamber with a constant temperature $\left(30^{\circ} \mathrm{C}\right)$. The humidity was kept at $50 \%$ of WHC, and the pile was rotated every week to insure even distribution of the material and the femperature and to increase aeration.

\section{Analytical Methods}

The ash content was determined in an electric furnace $\left(12 \mathrm{~h}\right.$ at $\left.700^{\circ} \mathrm{C}\right)$. After treating the sludge with acid (to remove carbonates), the organic carbon was determined with a Carmhograph-12. Nitrogen was determined with a "Technicon" autoanalyzer, and the cation exchange capacity by using barium acetate $(\mathrm{pH}=8)$.

The separation of organic fractions from sludge was carried out as follows. The lipid fraction was extracted in a Soxhlet with petroleum ether $\left(40-70^{\circ} \mathrm{C}\right)$ during the course of $70 \mathrm{~h}$. The residual sludge was extracted with $0.1 \mathrm{~N} \mathrm{NaOH}$ under nitrogen, and the soluble 
extract was acidified to $\mathrm{pH} 1$, thereby obtaining a soluble, colourless fraction and a grayish precipitate $(\mathrm{OCF})$. An attempt was made to concentrate the first fraction in insoluble polyvinylpyrrolidone, but this fraction was not adsorbed on the resin, suggesting a strongly aliphatic character [9]. For that reason, the acid-soluble fraction of this sludge was considered to be highly different from the soil fulvic acids and was not studied. The percentages (as $\mathrm{C}$ ) of the above fractions were determined in 10-ml decarbonated and desiccated aliquots, using the Carmhograph analyzer.

Since our previous analyses showed an important lipid contribution to the composition the OCF (even after exhaustive lipid extraction of the sludge sample), these freezedried, "crude" OCF's were submitted to ultrasonic shaking in petroleum ether, followed by a $12 \mathrm{~h}$ continuous extraction in a Blount micro-extractor; the process was repeated during the period of a week, using fresh solvent every day. These treatments were found to be highly effective to remove lipids physically "entrapped" in the OCF, most of them presumably introduced into this fraction by adsorption of the lipids released from sludge during the alkaline extraction.

\section{Characterization of the Sludge OCF}

The elementary composition was determined in a CHN analyzer Perkin-Elmer $240 \mathrm{C}$. The molecular size distribution was studied using Sephadex G-50, recording the densitometric curves at $450 \mathrm{~nm}$. Spectroscopic parameters in the visible range were determined using solutions of $136 \mathrm{mg} / \mathrm{l} \mathrm{C} \mathrm{[12],} \mathrm{and} \mathrm{the} \mathrm{E4/E6} \mathrm{ratio} \mathrm{refers} \mathrm{to} \mathrm{the} \mathrm{relation} \mathrm{between}$ extinctions at 465 and $665 \mathrm{~nm}$. The analysis of amino acids was carried out in a Biotronik amino acid analyzer LC 7000 , after hydrolysis with $6 \mathrm{M} \mathrm{HCl}$. The hydrolyzable sugars were studied by GC as alditol acetates [13], using a Perkin Elmer Sigma-3-10 GC system, and identified by their coincidence with the retention times of authentic compounds.

Oxidative degradation of the OCF's was carried out in two steps, first using a mild reagent (potassium persulphate) [14], then reoxidizing the persulphate-resistant material by alkaline permanganate degradation [15]. In both cases, the oxidation products were extracted with ethyl acetate in a liquid-liquid extractor during the course of $12 \mathrm{~h}$. As in the case of the lipid fraction, these compounds were methylated with ethereal diazomethane, then separated and identified in a GC-MS system Hewlett Packard 5992 B. The identity of chromatographic peaks was estabilished in terms of their mass spectra, but also by comparison with the retention times of authentic compounds. The column used was a 20-m cross-linked capillary OV-101, and the oven temperature was programmed at between $25^{\circ}$ and $270^{\circ} \mathrm{C}$ with a rate of $5 \% \mathrm{~min}$.

\section{Results}

The whole sludge sample had about $60 \%$ organic matter and $2 \%$ nitrogen $(\mathrm{C} / \mathrm{N}=17$, Table 1). The principal exchange cations were $\mathrm{Ca}^{2+}$ and $\mathrm{Mg}^{2+}$. The exchange complex was saturated (absence of exchangeable $\mathrm{H}^{+}$) and the total cation exchange capacity, 115 meq/100 g, was proportional to the high content of organic matter (T/C). The 4 -month composting process was responsible for a $22 \%$ loss of weight, a value similar to that reported elsewhere [16]. The content of organic matter decreased, but the $\mathrm{N}$ content remained constant; a $\mathrm{C} / \mathrm{N}$ ratio of 12 was observed in the composted sludge. Nevertheless, 


\begin{tabular}{|c|c|c|c|c|c|c|c|c|c|c|c|c|}
\hline \multirow[b]{2}{*}{ Sample } & \multirow[b]{2}{*}{$\begin{array}{l}\% w t \\
\text { loss }\end{array}$} & \multirow[b]{2}{*}{$\begin{array}{c}\% \\
\text { ash } \\
\end{array}$} & \multirow[b]{2}{*}{$\begin{array}{l}\% \mathrm{C} \\
\text { org. }\end{array}$} & \multirow[b]{2}{*}{$\% N$} & \multirow[b]{2}{*}{$\mathrm{C} / \mathrm{N}$} & \multirow[b]{2}{*}{$\begin{array}{l}\% N . \\
\text { loss }\end{array}$} & \multicolumn{6}{|c|}{ Exchange cations } \\
\hline & & & & & & & $\mathrm{Na}^{+}$ & $\mathrm{K}^{+}$ & $\mathrm{Ca}^{2+} \mathrm{Mg}^{2+}$ & $\mathrm{H}^{+}$ & $\mathrm{T}$ & $T / C$ \\
\hline $\begin{array}{l}\text { Original } \\
\text { sludge }\end{array}$ & - & 39.8 & 34.3 & 1.97 & 17.4 & - & 8.3 & 1.0 & 88.816 .9 & 0.0 & 115.0 & 3.3 \\
\hline $\begin{array}{l}\text { 4-month } \\
\text { composted }\end{array}$ & 22.4 & 51.3 & 23.9 & 1.98 & 12.1 & 22.0 & 10.9 & 1.3 & 112.019 .7 & 0.0 & 143.9 & 6.0 \\
\hline
\end{tabular}

$\mathrm{T}=$ Total exchange capacity, meq/100g.

when calculating the nitrogen content in terms of the original weight before composting, a $22 \%$ loss of $\mathrm{N}$ was also observed.

The total exchange capacity increased after composting, as did the $\mathrm{T} / \mathrm{C}$ ratio, indicating a greater "maturity" of the organic matter in the composted sludge, with a greater proportion of cation-complexing functional groups.

The alkali-extractable fractions of sludge made up to $14 \%$ of total $\mathrm{C}$, and the OCF represented about $10 \%$ of total $\mathrm{C}$ (Table 2). After composting, the percentage of lipids and acid-soluble fractions underwent a small reduction, but the OCF greatly decreased in comparison with uncomposted sludge. Several physico-chemical parameters of the OCF's are given in Table 3. According to the experimental procedure described above, the "crude" OCF was also studied after physical removal of the lipid fraction and degradation with $\mathrm{K}_{2} \mathrm{~S}_{2} \mathrm{O}_{8}$, a mild reagent which removes loosely linked organic compounds. These pretreatments were carried out in order to eliminate the "non-humic" matter associated with, or co-extracted with, the OCF, in a attempt to "purify" this fraction and increase its chemical similarity with humic acids.

Table 2 Eflect of composting on the yields of extractable fractions from sewage sludge.

\begin{tabular}{lccccc}
\hline Sample & & Lipid fraction & $\begin{array}{c}\text { Alkali-soluble } \\
\text { acid-insoluble } \\
\text { (FA-like) }\end{array}$ & $\begin{array}{c}\text { Alkali-soluble } \\
\text { acid-insoluble } \\
\text { (HA-like)(=OCF) }\end{array}$ & $\begin{array}{c}\text { Alkali-insoluble } \\
\text { (humin-like) }\end{array}$ \\
\hline Original sludge & 1 1) & 1.35 & 1.50 & 3.30 & 28.15 \\
& $2)$ & 3.94 & 4.37 & 9.62 & 82.07 \\
& & & & & \\
4-month compos- & $1)$ & 0.84 & 1.32 & 0.98 & 20.76 \\
ted sludge & 2) & 3.51 & 5.52 & 4.11 & 86.85 \\
& 3) & 0.65 & 1.03 & 0.76 & 16.13 \\
\hline
\end{tabular}

1) Grams of $C$ from the different fractions in $100 \mathrm{~g}$ sludge sample.

2) Grams of $C$ from the different fractions in $100 \mathrm{~g}$ sludge organic $C$.

3) Grams of $C$ from the different fractions after composting $100 \mathrm{~g}$ original sludge. 


\section{Elementary Composition}

The percentages of $\mathrm{C}, \mathrm{H}, \mathrm{O}$ and $\mathrm{N}$ of the OCF's were different from those of soil humic acids (Table 3). In particular, the atomic $\mathrm{H} / \mathrm{C}$ ratios were comparatively high, suggesting a predominance of alkyl compounds [17]. After lipid extraction, the atomic $\mathrm{O} / \mathrm{C}$ ratio increased, which corresponds to the release of non-polar compounds. The latter parameter further increased after the persulphate treatment of the uncomposted sludge (which eliminated an additional lipid fraction). As expected, the OCF from composted sludge showed an increased $\mathrm{O} / \mathrm{C}$ atomic ratio. The behaviour of the OCF from the composted sludge tended to be more similar to that of humic acids: lipid extraction induces a relative increase of oxygen-containing groups, but the persulphate treatment induces decarboxylation typical of hydrolytic processes [18]. The changes in the $N$ content were also significant: composting produced a relative increase (lower $\mathrm{C} / \mathrm{N}$ ratio in the composted OCF's), and lipid extraction and persulphate degradation produced, respectively, an extraction of components without nitrogen, and removal of the easily degradable (carbohydrate and protein) moieties of the OCF. Based on this information the hydrolyzable nitrogen was calculated to $70 \%$ (value similar to that of fresh biomass), suggesting a predominant peptidic nature of the $\mathrm{N}$ in the OCF. This last parameter decreased as a consequence of composting.

\section{Physical Characteristics}

The specific extinction ( $450 \mathrm{~nm}$ ) of OCF's was very low in comparison to any soil organic fraction, and the E4/E6 ratio was also relatively low (Table 3 ). This last parameter was affected by composting, illustrating the changes in the molecular sizes of the sludge OCF's [19]. The MW distribution was studied by gel filtration, which revealed relatively high molecular sizes for this sludge fraction (Table 4). The molecular sizes are affected, in part, by the adsorption of hydrophobic fractions on the OCF. It was found that after the petroleum ether treatment, the separated fractions became more defined, with

Table 3 Analytical characteristics of sludge polymers (HA-like) betore and after 4 months of composting.

\begin{tabular}{|c|c|c|c|c|c|c|c|c|c|c|c|}
\hline \multirow[b]{2}{*}{ HA-like } & \multirow[b]{2}{*}{ Treatment } & \multicolumn{5}{|c|}{ Elementary composition } & \multicolumn{2}{|c|}{$\begin{array}{l}\text { Atomic } \\
\text { ratios }\end{array}$} & \multirow{2}{*}{$\begin{array}{c}\% \\
\text { hydro- } \\
\text { lyzable } \\
N\end{array}$} & \multicolumn{2}{|c|}{$\begin{array}{l}\text { Spectroscopy/ } \\
\text { parameters }\end{array}$} \\
\hline & & $\% \mathrm{C}$ & $\% H$ & $\% O$ & $\% N$ & $\mathrm{C} / \mathrm{N}$ & $\overline{\mathrm{H} / \mathrm{C}}$ & $\mathrm{O} / \mathrm{C}$ & & $\begin{array}{l}\mathrm{E} 4(136 \\
\mathrm{ppm} \mathrm{C})\end{array}$ & E4/E6 \\
\hline
\end{tabular}

\begin{tabular}{|c|c|c|c|c|c|c|c|c|c|c|c|}
\hline \multirow[t]{3}{*}{ Original } & $\cdots$ & 55.9 & 7.9 & 33.5 & 2.7 & 20.7 & 1.7 & 0.4 & - & 0.12 & 3.6 \\
\hline & $\begin{array}{l}\text { Lipid } \\
\text { extraction }\end{array}$ & 45.3 & 5.8 & 43.0 & 5.9 & 7.7 & 1.5 & 0.7 & 68.7 & 0.14 & 4.5 \\
\hline & $\begin{array}{l}\mathrm{K}_{2} \mathrm{~S}_{2} \mathrm{O}_{8} \\
\text { oxidation }\end{array}$ & 37.1 & 4.4 & 55.8 & 2.7 & 13.7 & 1.4 & 1.1 & - & n.d. & \\
\hline \multirow[t]{3}{*}{ 4-month } & $\cdots$ & 47.3 & 6.1 & 41.4 & 5.2 & 9.0 & 1.5 & 0.6 & - & 0.20 & 5.0 \\
\hline & $\begin{array}{l}\text { Lipid } \\
\text { extraction }\end{array}$ & 32.7 & 3.9 & 56.6 & 6.8 & 4.8 & 1.4 & 1.3 & 60.8 & 0.17 & \\
\hline & $\begin{array}{l}\mathrm{K}_{2} \mathrm{~S}_{2} \mathrm{O}_{8} \\
\text { oxidation }\end{array}$ & 43.0 & 4.9 & 48.4 & 3.7 & 11.6 & 1.4 & 0.8 & - & n.d. & \\
\hline
\end{tabular}


Table 4 Gel tiltration (Sephadex G-50) of organic colloidal fractions from sewage sludges.

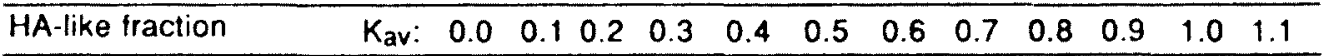

Uncomposted sludge:

$\begin{array}{lllll}\text { Original } & 40.0 & 56.0 & & 4.0 \\ \text { Lipid extracted } & 59.5 & 29.8 & 3.6 & 7.1\end{array}$

4-month composted

sludge:

\begin{tabular}{lllllll} 
Original & 28.0 & 36.0 & 28.0 & & \multicolumn{2}{c}{8.0} \\
Lipid extraction & 31.8 & & 47.6 & 7.9 & 12.7 \\
\hline
\end{tabular}

Percentages of the total area of the densitometric curve registered at $450 \mathrm{~nm}$.

the development of well-defined peaks of low molecular size $\left(\mathrm{K}_{\mathrm{av}} 0.3-1.1\right)$. The significant decrease of the molecular size after composting suggested that the readily biodegradable constituents of the OCF's consisted of the polymers with a high molecular weight.

\section{Infrared Spectroscopy}

The IR spectra of lipid-extracted OCF's are shown in Fig. 1. The IR spectra of the uncomposted samples seem to correspond to a complex mixture of fatty, peptidic and polysaccharide substances. Alkyl vibrations were prominent at around $2420 \mathrm{~cm}^{-1}$, and they were also responsible for the bands at 1470 and $720 \mathrm{~cm}^{-1}$.

The sharp vibration near $1720 \mathrm{~cm}^{-1}$ may correspond to esters, ketones or acids; the carboxyl contribution was probable, as suggested by the broad band near $2600 \mathrm{~cm}^{-1}$. Both amide bands (1660 and $1550 \mathrm{~cm}^{-1}$ ) were intense. No definitive evidence for aromatic

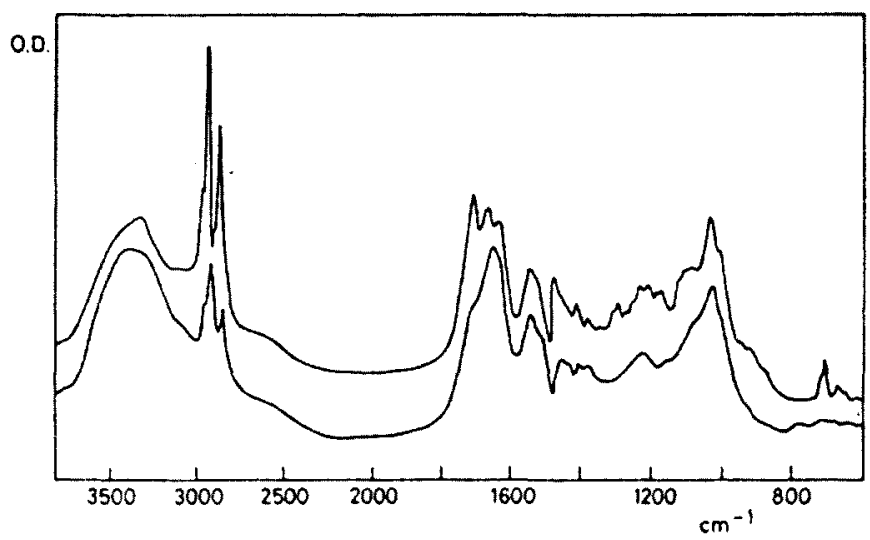

Flgure 1 Intrared spectra of the alkali-soluble, acid-insoluble fractions from sewage sludge, after light petroleum, ultrasonic treatment. Top, original sludge; below, 4-month composted sludge. 
material was found (the band at $1510 \mathrm{~cm}^{-1}$ was only a shoulder and the band at $1610 \mathrm{~cm}^{-1}$ was too unspecific). The intensity in the region of $1030 \mathrm{~cm}^{-1}$ suggested a certain proportion of polysaccharide. Other bands of the spectrum may be assigned according to methods described in the literature $[20,21]$, which also suggests the presence of sulfonic groups. After composting, the alkyl bands decreased, but the intense bands of the $\mathrm{N}$-containing components and polysaccharides remained. The $\mathrm{C}=\mathrm{O}$ vibrations of this composted sample were not strong, as opposed to soil humic fractions.

\section{Degradative Studies}

After acid hydrolysis of the OCF most of its constituents split off and could be analysed. The OCF's represented a very high protein content (Table 5). The total amino acid concentration amounted to $30 \%$ of this sludge fraction. Glutamic and aspartic acids, leucine and phenylanine were the predominant molecules. After composting, the protein fraction decreased by $50 \%$, phenylalanine and lysine being the less resistant to aerobic transformation. In general, the amino acid patterns and the resistance to degradation of individual molecules are rather similar to those described for soil humic fractions [22].

The hydrolyzable sugars (Table 6) were not predominant (about $5 \%$ ) in the OCF, but relatively important, if compared with the proportion of soluble polysaccharides in humus. Glucans were the predominant constituents of this fraction, but galactose, man-

Table 5 Effect of composting on the amino acid distribution of the OCFs from sewage sludge.

\begin{tabular}{lrrrrr}
\hline Compound & Uncomposted sludge & \multicolumn{2}{c}{ Composted sludge } & $\begin{array}{r}\text { Relative losses af- } \\
\text { ter composting }\end{array}$ \\
\hline Alanine & 2.22 & $(7.38)$ & 1.55 & $(8.07)$ & 45.8 \\
Arginine & 1.76 & $(5.85)$ & 0.95 & $(4.95)$ & 58.1 \\
Aspartic acid & 3.51 & $(11.67)$ & 2.56 & $(13.33)$ & 43.4 \\
Phenylalanine & 2.72 & $(9.04)$ & 1.22 & $(6.35)$ & 65.2 \\
Glycine & 1.80 & $(5.99)$ & 1.41 & $(7.34)$ & 39.2 \\
Glutamic acid & 3.95 & $(13.16)$ & 2.86 & $(14.91)$ & 43.8 \\
Hystidine & 1.06 & $(3.52)$ & 0.76 & $(3.96)$ & 44.4 \\
Isoleucine & 1.20 & $(3.99)$ & 0.67 & $(3.49)$ & 56.7 \\
Leucine & 2.77 & $(9.21)$ & 1.55 & $(8.07)$ & 56.6 \\
Lysine & 1.42 & $(4.72)$ & 0.67 & $(3.49)$ & 63.4 \\
Proline & 1.44 & $(4.79)$ & 0.99 & $(5.16)$ & 46.6 \\
Serine & 1.72 & $(5.72)$ & 1.10 & $(5.73)$ & 50.4 \\
Tyrosine & 1.30 & $(4.32)$ & 0.78 & $(4.06)$ & 53.4 \\
Threonine & 1.64 & $(5.45)$ & 1.11 & $(5.78)$ & 47.5 \\
Valine & 1.56 & $(5.19)$ & 1.02 & $5.31)$ & 49.3 \\
& & & & & \\
Total aminoacids & 30.07 & $(100.00)$ & 19.20 & $(100.00)$ & 50.4 \\
\hline
\end{tabular}

$\mathrm{g}$ amino acid in $100 \mathrm{~g} \mathrm{HA}$-like fraction (parenthesis: percentage of the total amino acid content). 
Table 6 Effect of composting on the sugar distribution of the OCFs trom sewage sludge."

\begin{tabular}{lrrrrr}
\hline Compound & Uncomposted sludge & \multicolumn{2}{c}{ Composted sludge } & $\begin{array}{c}\text { Relative losses } \\
\text { after composting }\end{array}$ \\
\hline Glucose & 2.48 & $(48.35)$ & 1.30 & $(32.12)$ & 59.3 \\
Galactose & 0.49 & $(9.55)$ & 0.28 & $(6.91)$ & 55.6 \\
Maninose & 0.49 & $(9.55)$ & 0.62 & $(15.30)$ & 1.8 \\
Glucosamine & 1.24 & $(24.17)$ & 1.29 & $(31.85)$ & 19.2 \\
Galactosamine & 0.43 & $(8.38)$ & 0.56 & $(13.82)$ & -1.1 \\
& & & & & \\
Total sugars & 5.13 & $(100.000)$ & 4.05 & $(100.00)$ & 38.7 \\
\hline
\end{tabular}

- g sugar in $100 \mathrm{~g} \mathrm{HA}$-like fraction (parentheses: percentage of the total hydrolyzable sugars).

nose and aminosugars were also detected. After composting, the polysaccharide fraction decreased to nearly $40 \%$ due to the high relative losses of glucose and galactose. On the other hand, mannose and aminosugars were found to be more resistant to composting.

The composition of fatty acids in free lipid fractions was studied for comparison with those incorporated in the OCF's. The proportion of alkanes was relatively small; the most abundant fraction of lipids consisted of $\mathrm{n}$-fatty acids in the $\mathrm{C}_{12}-\mathrm{C}_{28}$ range. The principal acids were palmitic, stearic and myristic [23]. The C18 unsaturated acids (oleic and linoleic) were also very abundant, whereas palmitoleic acid was not predominant (Table 7).

The distribution pattern of free fatty acids was rather constant after composting. As expected, the total proportion of unsaturated chains decreased, and the total proportion of the chains longer than $\mathrm{C}_{20}$ (presumably derived from epicuticular waxes from higher plants); considered highly resistant to degradation [24,25], increased in amount. The lipid fractions separated from the OCF's after ultrasonic treatment in petroleum ether were very abundant, making up $41 \%$ and $51 \%$ of this fraction from the uncomposted and the composted sample, respectively. The composition of these fractions was rather different to that of free lipid fractions, since they included significant amounts of the branched fatty acids with the configuration iso and anteiso, $\left(\mathrm{C}_{14}-\mathrm{C}_{19}\right)$. These compounds are typical of bacteria and suggest important microbial contribution $[25,26]$.

Successive degradation (persulphate oxidation followed by alkaline permanganate oxidation) yielded compounds similar to those of the soil humic polymers, but in different proportions: most of the products released were alkanoic acids. In Fig. 2 the major chromatographic peaks are labelled and classified in aliphatic series, and in Table 8 the proportions of the different types of products are calculated as percentages of the total chromatographic area, for direct comparison. The degradation yields obtained were as follows: $67 \%$ of the uncomposted OCF was degraded by $\mathrm{K}_{2} \mathrm{~S}_{2} \mathrm{O}_{8}$ (18\% of ethyl acetatesoluble products, for the GC-MS analyses) and $71 \%$ of the composted OCF was degraded by $\mathrm{K}_{2} \mathrm{~S}_{2} \mathrm{O}_{8}(21 \%$ soluble in ethyl acetate). The persulphate residues were degraded totally 
Table 7 Fatty acid distribution in total sewage sludges and their colloidal organic fractions."

$$
\begin{array}{lllllllllllllll}
C_{12} & C_{13} & C_{14 b} & C_{14 b} & C_{14} & C_{15 b} & C_{15 b} & C_{15} & C_{16 b} & C_{16: 1} & C_{16} & C_{17 b} & C_{17 b} & C_{17} & C_{18: 2}
\end{array}
$$

$\begin{array}{llllllllllllllll}\text { F.U } & 0.5 & 0.1 & 0.0 & 0.1 & 9.6 & 0.0 & 0.0 & 1.0 & 0.0 & 0.3 & 56.2 & 0.0 & 0.0 & 0.5 & 9.8 \\ \text { F.C } & 0.2 & 0.0 & 0.0 & 0.0 & 6.8 & 0.0 & 0.0 & 5.8 & 0.0 & 1.8 & 54.8 & 0.0 & 0.0 & 0.3 & 6.5 \\ \text { FHA.U } & 2.8 & 0.3 & 0.2 & 0.1 & 15.0 & 1.1 & 1.1 & 1.9 & 0.0 & 0.0 & 36.0 & 9.8 & 0.0 & 1.6 & 0.0 \\ \text { FHA.C } & 9.4 & 0.3 & 0.7 & 0.6 & 11.5 & 2.5 & 2.8 & 1.8 & 0.0 & 2.2 & 32.7 & 0.0 & 1.7 & 1.2 & 1.4\end{array}$

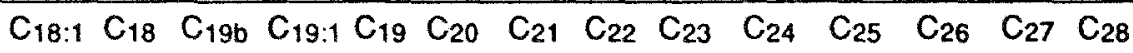

\begin{tabular}{lrrrrrrrrrrrrrr} 
F.U & 7.0 & 10.9 & 0.0 & 0.0 & 0.4 & 0.4 & 0.2 & 0.7 & 0.1 & 1.6 & 0.2 & 0.2 & 0.1 & 0.1 \\
F.C & 3.3 & 12.8 & 0.0 & 0.0 & 0.2 & 0.7 & 0.2 & 1.3 & 0.2 & 3.7 & 0.3 & 0.3 & 0.5 & 0.3 \\
FHA.U & 10.1 & 12.9 & 0.3 & 2.4 & 0.3 & 3.0 & 0.1 & 0.2 & 0.1 & 0.1 & 0.2 & 0.2 & 0.0 & 0.0 \\
FHA.C & 13.7 & 11.5 & 0.8 & 1.0 & 1.0 & 1.9 & 0.3 & 0.7 & 0.1 & 0.3 & 0.1 & 0.1 & 0.0 & 0.0 \\
\hline
\end{tabular}

- Percentages of total content of fatty acids.

Abbreviations used: $F$, free fatty acids of sludge; FHA, fatty acids associated with the organic colloidal fraction (ultrasonic treatment + petroleum ether extraction); U, uncomposted; C, 4-months composted.

by $\mathrm{KMnO}_{4}$, yielding $22 \%$ ethyl acetate products (OCF from uncomposted sludge), and $18 \%$ in the case of the composted sample.

The products released by persulphate may be interpreted as the degradation products of the more labile polymers present in the OCF's (e.g. glycolipids). The proportion of hydrocarbons was small; the most abundant products were fatty acids. Low proportions of dialkyl phthalates (diethyl, dibutyl, diisobutyl, and dicyclohexyl) were also found; these compounds seem to be frequent in sludges [27].

The lipid fraction released by acid degradation with persulphate was comparatively simple: the $\mathrm{C}_{14}-\mathrm{C}_{18} \mathrm{n}$-chains were dominant. The content of alkanoic $\alpha, \omega$-diacids (mainly $\mathrm{C}_{18}$ ) amounted to around $7 \%$ of the total volatile products released by persulphate. No aromatic acid was found in persulphate-removable forms, but hydroxy fatty acids represented $7 \%$ or $4 \%$ of the volatile products before and after composting, respectively. The products obtained after permanganate degradation confirmed the strongly aliphatic character of the OCF. No alkanes were detected, and the fatty acid fraction was also predominant, including important proportions of iso and anteiso chains. The alkanoic $\alpha$, $\omega$-diacids $\left(\mathrm{C}_{6}-\mathrm{C}_{10}\right)$ amounted to nearly $40 \%$ of the permanganate degradation products of the original OCF, but that value decreased to $10 \%$ after composting. The $\beta$-hydroxy fatty acids and a smaller amount of $\omega$-OH acids were also present, and aromatic acids (typical constituents of soil humic fractions) were represented only in minimal proportions, even after the 4-month composting process. 

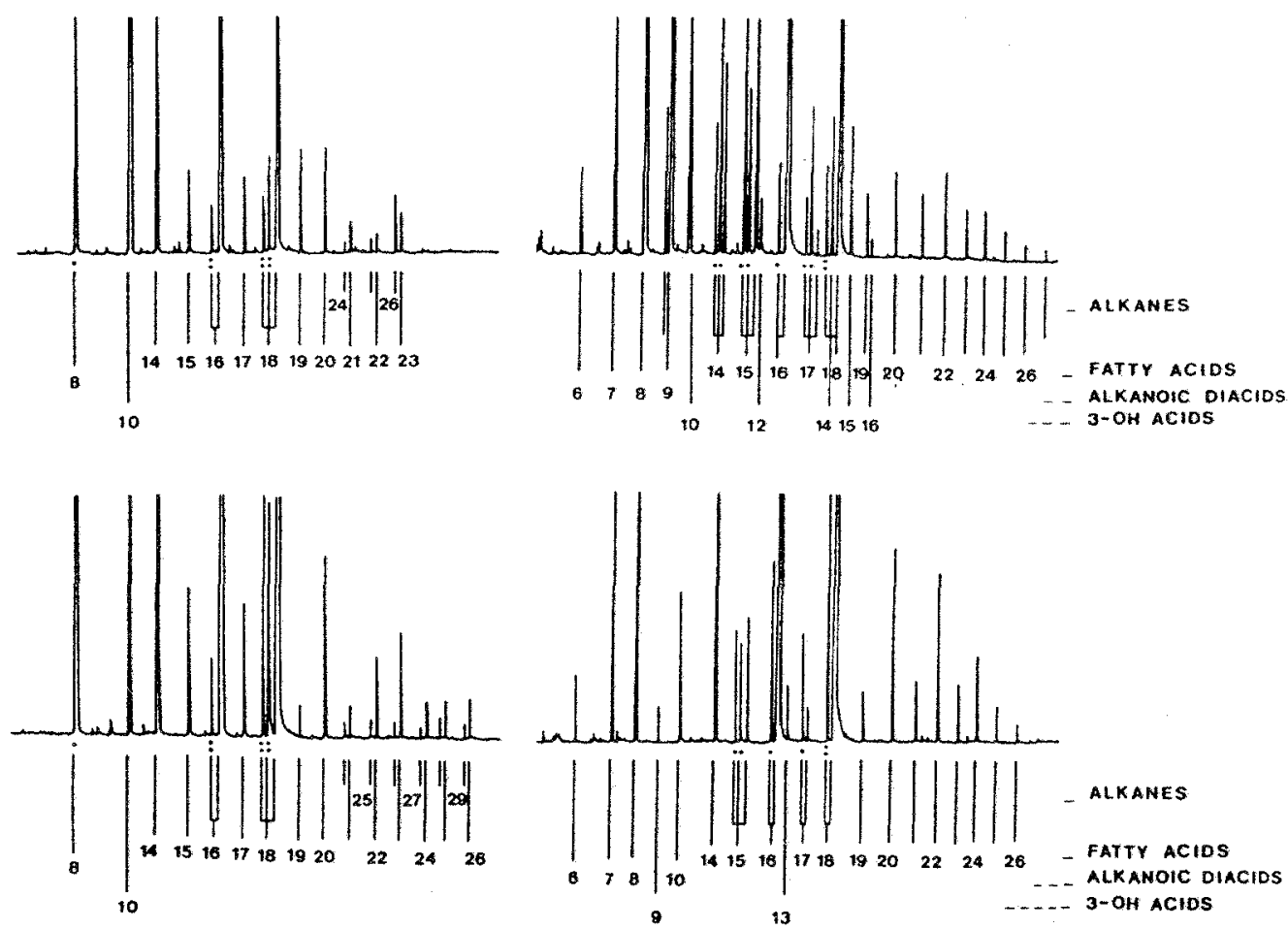

Flgure 2 Left: chromatographic separation of the persulphate degradation products from the OCF from uncom posted sludge (A) and from the 4-month composted sludge (B). Right: products released by alkaline permang anate oxidation from the persulphate degradation residue ( $=$ branched, : $=$ unsaturated).

Table 8 Effect of composting on the relative yields of degradation products of the OCF from sewage sludge afte degradation with $\mathrm{K}_{2} \mathrm{~S}_{2} \mathrm{O}_{8}$ followed by alkaline $\mathrm{KMnO} 4$ oxidation of the persulphate residue."

\begin{tabular}{lcccc}
\hline \multirow{2}{*}{ Type of compound } & \multicolumn{2}{c}{$\mathrm{K}_{2} \mathrm{~S}_{2} \mathrm{O}_{8}$} & \multicolumn{2}{c}{$\mathrm{KMnO}_{4}$} \\
& $\begin{array}{c}\text { Uncomposted } \\
\text { sludge }\end{array}$ & $\begin{array}{c}\text { Composted } \\
\text { sludge }\end{array}$ & $\begin{array}{c}\text { Uncomposted } \\
\text { sludge }\end{array}$ & $\begin{array}{c}\text { Composted } \\
\text { sludge }\end{array}$ \\
\hline Alkanes & 2.31 & & & \\
Fatty acids: Total & 82.29 & 79.88 & 57.00 & 0.00 \\
$\quad$ Branched & 0.00 & 0.00 & 13.95 & 83.55 \\
$\quad$ Unsaturated & 3.03 & 5.62 & 1.61 & 9.42 \\
Alkanoic $\alpha, \omega$-diacids & 5.91 & 7.10 & 37.23 & 10.00 \\
OH fatty acids & 6.77 & 4.29 & 2.88 & 2.15 \\
Phenolic acids & 0.00 & 0.00 & 0.10 & 0.30 \\
Benzene carboxylic acids & 0.00 & 0.00 & 1.20 & 1.80 \\
\hline
\end{tabular}

* Percentages of the total volatile compounds, as methyl esters. 


\section{Conclusions}

The analytical results suggest that the composition of the OCF from the domestic sewage sludge was very different from soil humic acids. These sludge fractions mainly consisted of protein with a certain proportion of carbohydrates, incorporating a large amount of lipids by physical or chemical bonds. A portion of the OCF was found to be resistant to mildly oxidative procedures - and presumably to biological degradation- [28, 29 ], but they were also different in composition than any humic fraction. The high proportion of short-chain fatty acids, and the presence of $\beta$-hydroxy acids (both frequently showing the iso and anteiso configurations) may be interpretated as the effect of microorganisms responsible for the formation of sludge polymers, such as bacterial lipopolysaccharides. On the other hand, the small amounts of $\omega$-OH acids could be attributed to the presence of altered biopolyesters from higher plant wastes [30].

The very small amount of aromatic constituents was not sufficient to justify a conspicuous contribution of lignin or humic-type polymers. After composting, the physico-chemical properties of the OCF became more similar to those of humic substances, but, from a structural viewpoint, they cannot be considered to contain a predominant fraction of a polymer similar to a terrestrial humic acid.

Nevertheless, even when considering the peculiar composition of the OCF's from composted sludges, it was observed that they coincided with humus fractions in regards to several physico-chemical properties which are adequate to improve soil physical properties (ie., molecular size, cation-complexing functional groups, tendency towards association both with hydrophobic and hydrophilic molecules). The very high proportion of free and linked lipids may be unfavourable to soil properties, because it is well known that these substances may enhance the water-repellent properties of soil. This circumstance is not, however, frequently reported, probably due to the fact that most sludge lipids are of low molecular size and may be considered as easily biodegradable in soil [24].

The advantages and inconveniences of extended composting of sludge must be carefully evaluated. Aerobic conditions do transform sludge into a substratum with increased stability and a certain resemblance to soil humus in terms of several of the parameters examined. But composting also causes dramatic losses of important constituents, such as the total organic matter, protein, and the total content of the OCF. In addition, during the 4-month experiment, the OCF did not tum into a polymer similar to humic substances. These facts suggest that composting time should be calculated in terms of the period necessary for the destruction of harmful microorganisms and phytotoxic substances $[31,32]$ since the composition of the original sludge does not seem to be especially rich in materials of a prehumic nature.

\section{References}

1. Truesdale, G.A. and R.A. Wellings. Agrochim. 27:79 (1983).

2. Hunter, J.V. and H. Heukelekian. Journal WPCF 37:1142 (1965).

3. Lineres, M., C. Juste, J. Tauzin and A. Gomez. In: P. L'Hermite, Ed., Processing and Use of Organic Sludge and Liquid Agricultural Wastes. pp. 290-303. (Dordrecth: D. Reidel Pub. Co., 1985). 
4. Kladivko, E.J. and D.W. Nelson. Journal WPCF 51:325 (1979).

5. Sommers, L.E., D.W. Nelson, J.E. Yahner and J.V. Mannering. Proc. Indiana Acad. Sci. 8 (1973).

6. Sommers, L.E. J. Environ. Qual. 6:225 (1977).

7. Almendros, G., E. Dorado and A. Polo. In: Recuperacion de Recursos de los Residuos. Ter gias. pp 405-416 (Proc. II. Congreso Nacional. Soria, Spain, 1984).

8. Almendros, G., A. Polo and E. Dorado. Agrochim. 27:439-454 (1983).

9. de Nobili, M., G. Cercignani and L. Leita. In: J. H. Williams, G. Guidi and P. L'Hermite Long-term Effects of Sewage Sludge and Farm Slurries Applications, pp. 204-209. (Lo Elsevier, 1985).

10. Hohla, G.N., R.L. Jones and T.D. Hinesly. J. Environ. Qual. 7:559 (1978).

11. Boyd, S.A., L.E. Sommers and D.W. Nelson. Soil Sci. Soc. Am. J. 44:1179 (1980).

12. Kononova, M.M. Soil Organic Matter (London: Pergamon Press, 1961).

13. Laine, R.A., W.J. Esselman and C.C. Sweeley. In: S.P. Colowick and N.O. Kaplan, Eds, Me in Enzymology, Vol 28, pp. 159-167. (New York/London: Academic Press, 1972).

14. Martin, F., C. Saiz-Jimenez and F. J. Gonzalez-Vila. Soil Sci. 132:200 (1981).

15. Matsuda, K. and M. Schnitzer. Soil Sci. 114:185 (1972).

16. Miller, R. H. J. Environ. Qual. 3:376 (1974).

17. Sposito, G., K. M. Holtzclaw and J. Baham. J. Soil Sci. Soc. Am. J. 40:691 (1976).

18. Riffaldi, R. and M. Schnitzer. Soil Sci. 115:349 (1973).

19. Chen, Y., N. Senesi and M. Schnitzer. Soil Sci. Soc. Am. J. 41:352 (1977).

20. Gerasimowicz, W.V., D.M. Byler and E.G. Piotrowski. Soil Sci. 136:237 (1983).

21. Sposito, G., G.D. Schaumberg, T.G. Perkins and M. Holtzclaw. Environ. Sci. Technol. 12 (1978).

22. Schnitzer, M. and S.U. Khan. Humic Substances in the Environment (New York: Dekker, 19

23. Viswanathan, C.V., B. Meera Bai and S.C. Pillai. Journal WPCF. 34:189 (1962).

24. Moucawi, J., E. Fustec, P. Jambu, A. Ambles and R. Jacquesy. Soil Biol. Biochem. 13:335 (19

25. Simoneit, B.R.T. and M.A. Mazurek. Atmospheric Environ. 16:2139 (1982).

26. Kaneda, T. J. Bacteriol. 93:894 (1967).

27. Strachan, S.D., D.W. Nelson and L.E. Sommers. J. Environ. Qual. 12:69 (1983).

28. Terry, R.E., D.W. Nelson and L.E. Sommers. Soil Sci. Soc. Am. J. 43:494 (1979).

29. Terry, R.E., D.W. Nelson and L.E. Sommers. J. Environ. Qual. 8:342 (1979).

30. Kolattukudy, P.E. and R.E. Purdy. Environ. Sci. Technol. 7:619 (1973).

31. Vigerust, E. In: J. H. Williams, G. Guidi and P. L'Hermite Eds, Long-term Effects of Sew Sludge and Farm Slurries Applications, pp. 168-176 (London: Elsevier, 1985).

32. Mori, T., A. Narita, T. Amimoto and M. Chino. Soil Sci. Plant. Nutr. 27:477 (1981). 